\title{
The adoption of a Laboratory-Based Education model as the foundation of a research university: Relevance to a university in Indonesia
}

\author{
Kifayah Amar ${ }^{1, ~ *, ~ S h u i c h i ~ I s h i h a r a d a ~}{ }^{2}$, Muhammad Ja'far Luthfi ${ }^{3}$, Budi Saksono ${ }^{4}$ \\ ${ }^{1}$ Industrial Engineering Department, Faculty of Science and Technology, UIN Sunan Kalijaga, Yogyakarta 55281, Indonesia \\ ${ }^{2}$ Kagoshima University Innovation Center, Venture Business Laboratory, Kagoshima University, Kagoshima 890-0065, Japan \\ ${ }^{3}$ Integrated Laboratory of Science and Technology, UIN Sunan Kalijaga, Yogyakarta 55281, Indonesia \\ ${ }^{4}$ Laboratory of Glycobiochiemisry and Nanobiotechnology, Graduate School of Science and Engineering, Kagoshima University, \\ Kagoshima 890-0065, Japan
}

\section{Email address:}

kifayah.amar@uin-suka.ac.id (K. Amar), ishi@eng.kagoshima-u.ac.jp (S. Ishiharada), jafar.luthfi@uin-suka.ac.id (M. J. Luthfi), saksonobudi@eng.kagoshima-u.ac.jp (B. Saksono)

\section{To cite this article:}

Kifayah Amar, Shuichi Ishiharada, Muhammad Ja'far Luthfi, Budi Saksono. The Adoption of a Laboratory-Based Education Model as the Foundation of a Research University: Relevance to a University in Indonesia. Education Journal. Vol. 3, No. 4, 2014 , pp. $229-234$. doi: $10.11648 /$ j.edu. 20140304.14

\begin{abstract}
The Laboratory-Based Education (LBE) model has been implemented by the majority of universities in Japan and has been proved to generate research, patents, and publications both nationally and internationally. Another indicator of success in Japanese LBE is seen in the independent research skills of the students. Data collected through this study shows that the Indonesian university under study (referred to as the 'research object'), still experiences a number of problems commonly faced by higher education in Indonesia; for instance, the low number of students who graduate on time, and the lack of research and research publications. These issues can be a barrier to achieving world class recognition and also influence the accreditation of the institution. This paper presents a revised layout of the environment in the research object which it is believed will help in the implementation of LBE. Changing the layout of laboratories to support LBE can accommodate the needs of final year students and assist them to focus on their final project. Benefits for academics include increased opportunities to generate publications and patents from projects with their students.
\end{abstract}

Keywords: Innovation, Higher Education, Laboratory-Based Education, Indonesia

\section{Introduction}

In 2011, the number of university students in Indonesia was only 4.8 million, 18.4 per cent of the total population of 19-24 year olds [1]. There are several reasons for this low number of students enrolled at university, such as lack of economic ability to support their study, or parents preferring to send their children overseas to study.

Higher education in Indonesia is controlled by several Ministries besides the Ministry of Education, e.g. Ministry of Religious Affairs (MORA), Ministry of Defense, and

This paper is an expanded version of a paper entitled Measuring the Readiness to Adopt a Japanese Laboratory-Based Education Model: The Case of Indonesia, presented at the 4th Asian Education Conference, Osaka, 24-28 October 2012.
Ministry of Health. This contrasts with other countries where higher education is normally controlled solely by the Ministry of Education. However, the various ministries in Indonesia are allocated generous funds for the respective areas of higher education controlled by them.

Improvements in the education sector, particularly in Indonesian higher education, must include those who attempt to compete at local, regional or even international levels, including those universities controlled by MORA. According to the latest data released by MORA, fifty two public institutions are controlled by this ministry [2].

Having regard to the fierce competition in the education sector and aim to become a research university, the higher institutions under MORA, in particular those offering study in science and technology fields, have to improve their academic performance by increasing community-based 
research, publications, patents and so on [3]. In addition, teaching style and teaching programs are two features that should be improved continuously. This kind of improvement will indirectly increase the quality of the university graduates required by stakeholders. The question that arises from this issue is how can this problem be addressed? Since innovation in higher education is important, the education model should be changed to a research-based style of education in order to generate more publications and patents. As observed by the first author of this paper, some higher institutions under MORA, as well as the majority of higher education institutions in Indonesia, are still using classroom teaching methods that are mainly based on textbooks.

Laboratory Based Education (LBE) is implemented by the majority of universities in Japan and has been proved to generate research, patents, and publications both nationally and internationally. The LBE model is believed to be the best foundation for research universities and it is possible to implement the model in MORA universities, particularly those that offer science and technology programs.

Several universities in Indonesia, such as the Institut Teknologi Sepuluh Nopember (ITS) and the Universitas Hasanuddin have started to follow Japanese universities and have implemented LBE. The adoption of LBE by these Indonesian universities is because of the significant benefit of this concept experienced by Japanese universities, e.g. more linkage to industry, more publications and a higher number of patent applications and granted applications year on year. According to a statistical report provided by the World Intellectual Property Organization [4], Japan was granted the highest number of patents on average prior to 2008 compared to the US and other leading countries such as China, Korea, UK, and Canada.

\section{Laboratory-Based Education}

The Laboratory-Based Education (LBE) model commonly implemented in Japanese universities is particularly relevant for students in their final year (Bachelor Year 4), Masters and $\mathrm{PhD}$ candidates. The implementation of LBE has successfully generated research publications and patents, both nationally and internationally. Besides these advantages, the LBE concept has several objectives, as follows [5]:

- To improve the quality and relevance of science and engineering education

- To increase the involvement of faculty members in research

- To increase student involvement in the laboratory

- To increase the interaction between faculty members and students

Laboratory-Based Education (LBE) can also improve the teaching style of academics and improve their critical thinking through research involvement. This is in line with Ragunath's [6] perspective in that it assures that education is not limited to teaching in the classroom only, but that includes conducting research and knowledge transfer to students. According to Davies [7], LBE is important because it can 'foster students' understanding of the process of scientific enquiry and the ways in which knowledge is created and validated, fitting well with a common institutional goal of linking research and teaching" (p. 5).

To implement LBE successfully, Japanese universities follow a specific design in the academic environment which is different to that of Indonesian universities. For example, the most visible difference in the academic environment in Japanese universities is shown by the closeness of the Sensei's office to their supervised students. The students (final year of Bachelor degree, Masters and $\mathrm{PhD}$ ) are provided with a work desk at which to work on their research project. Figure 1 shows the laboratory in a Japanese university which provides an appropriate environment for students to work on their research projects. Here, 'appropriate environment' refers to the provision of a desk, Internet access, online journal access, and a university student email account for receiving academic information. As mentioned previously, this situation differs from Indonesian universities, where it is not compulsory for students in their final year to join a laboratory. Students are required to work independently and having only irregular meetings with their supervisor; they do not have their own work space in the university because the laboratory is mainly used for laboratory sessions (see Figure 2).

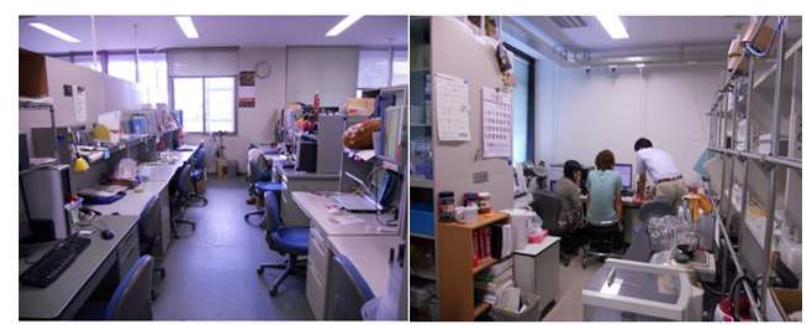

(a)

(b)

Figure 1. Laboratory in a Japanese University.

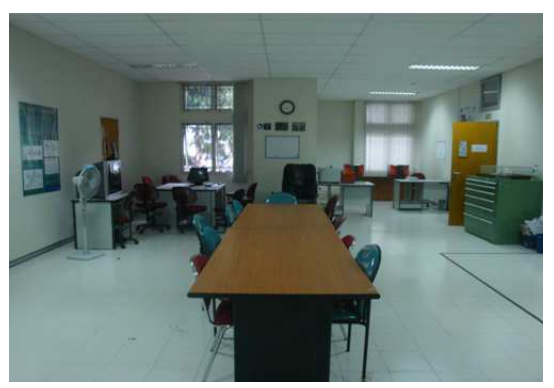

Figure 2. Laboratory in a University in Indonesia.

This situation highlights pertinent factors which may be a barrier to some academics outcomes, such as:

- Students and supervisors do not work closely together

- Lack of qualified publications

- Lack of patents generated because students work independently

- Students are not familiar with research work as they are rarely involved in their supervisor's project

Figures 1 and 2 illustrate laboratories in two different 
countries, Japan and Indonesia. Table 1 below explains further the general characteristic differences between laboratories in Japan and Indonesia.

Several of the points from Table 1 are highlighted below.

The laboratory structure in the research object has a top-down structure which generally features an organisational-style structure, i.e. top management, middle management and administrative staff. This structure serves to control many laboratories under an integrated laboratory situation, whereas in Japan, most laboratories are independent and have a very lean structure, comprising Professor, Associate Professor, Assistant Professor and students (final year of bachelor, Masters and $\mathrm{PhD}$ ).

The establishment of university-industry linkages in Japan has been a feature for several years; for example, Hane highlighted that the Gakujutsu Shinkokai or Japan
Society for the Promotion of Science (JSPS) held licenses for university patents with 58 local Japanese companies, of which the majority were small and medium enterprises [8]. This practice has continued to date to address industry needs through research in Japanese universities.

Based on the discussion of LBE above, the authors believe that the LBE model can also be used as a foundation for the development of the Research University concept in Indonesia and to further focus the commercialisation of research findings within these universities. The term 'Research University' is highly popular in Indonesia, even though many universities are still struggling to become successful research institutions in terms of the number of patents obtained, research conducted by their academics, the number of publications, and so on.

Table 1. General characteristics of laboratories in Japan and Indonesia.

\begin{tabular}{|c|c|c|}
\hline Aspect & Japan* & Indonesia** \\
\hline Definition & $\begin{array}{l}\text { A place designed for students to work on their research project that is either } \\
\text { attached to the experimental laboratory or an independent space }\end{array}$ & $\begin{array}{l}\text { A place for laboratory sessions or experiments } \\
\text { as part of the teaching process }\end{array}$ \\
\hline Laboratory structure & Lean & Top-down, has many layers \\
\hline $\begin{array}{l}\text { Facility related to } \\
\text { students }\end{array}$ & $\begin{array}{l}\text { A work desk set, equipped with Internet access, a university email account } \\
\text { to receive academic-related information, 24-hour laboratory access }\end{array}$ & None \\
\hline Funding & Research grant mainly from industry, government & $\begin{array}{l}\text { Funded mainly by university (for procurement, } \\
\text { operational, small research grant) }\end{array}$ \\
\hline Research environment & $\begin{array}{l}\text { 1. Regular meetings with research supervisor e.g. weekly meetings } \\
\text { 2. Close relationship between laboratory members (helping one another), } \\
\text { developing the culture of the laboratory } \\
\text { 3. Establishment of university-industry linkage (ease of obtaining particular } \\
\text { data and use of industrial equipment) }\end{array}$ & $\begin{array}{l}\text { 1. Irregular meetings with supervisor } \\
\text { 2. Students mostly working independently } \\
\text { 3. Lack of university-industry linkage }\end{array}$ \\
\hline
\end{tabular}

* Observation in a Japanese university (generally the same in other Japanese universities)

**Observation in a university under MORA in Indonesia (generally the same in other Indonesian universities)

Source: adapted from [9]

\section{Current Situation of the Object Institution}

Several Indonesian ministries, excluding the Ministry of Education, control higher institutions, such as the Ministry of Religious Affairs (MORA), Ministry of Defense and Ministry of Health, as noted above. Fifty-two public institutions are controlled by MORA [2]; however, only five MORA universities are included in the list of 100 top universities in Indonesia [10].

The section that follows will cover several important factors that influence the accreditation of an institution.

\subsection{Number of Students that Graduate on Time}

As observed by first author of this paper, some higher institutions under MORA as well as the majority of higher education institutions in Indonesia still practise classroom teaching based mainly on the use of textbooks. A similar situation was evident in New Zealand universities, as highlighted by Mintrom [11] in his study on pressures and dilemmas in managing the research function of the university. Mintrom [11] also noted that the general advancement of knowledge comes from research-based activities which are very different to general teaching in class, tutorials, laboratory sessions and so on. In Japan, academics are familiar with combining textbook information and research output for teaching material as a consequence of the high number of research activities undertaken. Moreover, the involvement of students conducting research projects with academics is also high in Japan. Final year students (Bachelor Year 4) join their desired laboratory in 6th semester, and some programs require that students join the laboratory earlier, e.g. in their 5th semester. This situation has positive implications for research for both academics and students; for example, there is greater focus on their research project, regular meetings between student and supervisor, etc. For academics, there is a high possibility of generating publications and patents from the research project which they supervise, whereas this situation rarely exist in the majority of Indonesian higher institutions, including MORA universities. The current practice in Indonesian universities has implications concerning the low number of students who are able to graduate on time; for instance, in one department of a MORA university, observed by the first author, the percentage of on-time graduations of Bachelor students had been below 30 per cent for four years. These results are 
presented in Table 2 .

Based on the national accreditation system, the number of on-time graduated students will impact on the accreditation point of the department itself. In Indonesia, there is a national accreditation evaluation designed the by Ministry of Higher Education which regularly evaluates the performance of higher institutions. The accreditation level is important because it impacts on the level of research and academic subsidies from government.

\subsection{Research and Publications}

There is an opinion that top universities must have a significant number of papers published in high impact journals. This cannot be argued, since we realise that the publication of research outcomes is important in ensuring that the university is known by others. Moreover, grading systems all over the world use research and publication as factors by which to measure university performance. For instance, Times Higher Education and even the national accreditation agency of Indonesia both identify publication and research as important aspects in ranking universities based on their performance.

In the research object department from which the authors have collected data, it is evident that even though academics have produced publications, the number is quite low. Figure 3 has presents a pie chart which shows the percentage of publications based on. Forty-nine per cent of the publications on international proceedings are from an international conference held in Indonesia. Publications in local journals accounted for thirty-eight percent, while no-one had published in high impact international journals. This data was summarised from the publication database for 2009 to 2012. Generally speaking, one academic produced four papers on average during the period 2009-2012.

This is in contrast to the number of publications produced by one laboratory in a faculty of a Japanese university. For instance, one research project by one academic produced seven papers published in high impact journals, either local or international.

Table 2. Percentage of on-time graduates of Bachelor degree.

\begin{tabular}{ccccc}
\hline Year of Study & Number of Graduated Students (4 Years) & Year of Graduated Student & Number of Students & Percentage \\
\hline 2005 & 5 & Graduated in 2009 & 43 & $11.63 \%$ \\
2006 & 6 & Graduated in 2010 & 49 & $12.25 \%$ \\
2007 & 11 & Graduated in 2011 & 48 & $22.92 \%$ \\
2008 & 8 & Graduated in 2012 & 91 & $8.79 \%$ \\
Total & 30 & & 231 & $12.99 \%$ \\
\hline
\end{tabular}

Source: Data was summarised from one department in the faculty of science and technology of research object

The implementation of LBE is the best solution for solving the problem of the lack of quality publications, particularly at an international level.

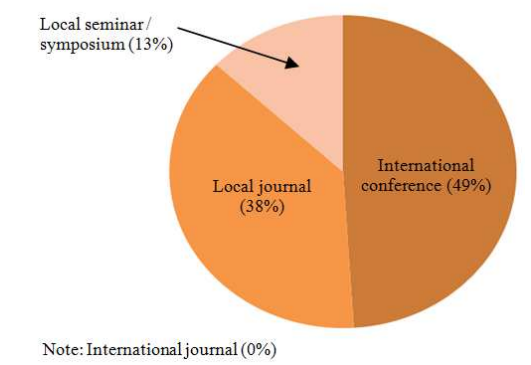

Figure 3. Percentage of publications 2009-2012.

Source: Data summarised from one department of the research object in Indonesia.

\subsection{Proposed Improvement}

The first and most urgent element in the adoption of the Laboratory-Based Education (LBE) model is to provide a supportive environment to students and academics to enable them to work intensively on their projects.

In the research object, there is the possibility of implementing LBE based on a previous measurement of the readiness and enthusiasm of laboratory people to adopt LBE which has shown positive results [9]. Nevertheless, several factors should be considered to permit the successful implementation of LBE in MORA universities. These factors, which we believe to be critical to the success of the implementation of LBE, are discussed briefly below.

\subsubsection{Laboratory Structure}

The current situation in the research object is that the structure within the laboratory is top-down, which follows a common organisational structure. There are more than fifteen laboratories within the integrated laboratory of the research object. From the observation of Japanese laboratories, it is clear that each laboratory has an individual structure and operates linearly in relation to other laboratories. This means that each laboratory is independent and has a similar structure (Professor, Associate Professor, $\mathrm{PhD}$ students, Masters students, and Bachelor Year 4 students) to other laboratories in the university. The structure is lean with few layers, which makes it easier for laboratory members to communicate with one another and work collaboratively on their research projects.

Introducing a lean structure to the research object laboratory may be worth considering to enhance research and also to build strong research groups within the faculty. However, changes to the structure of the laboratory may take some time because many laboratory personnel will view the changes with caution. 


\subsubsection{Layout Design of Object Institution}

To support LBE implementation, an appropriate environment for LBE must be set up. The current research object environment shows that some laboratories have free spaces that can be used for student desk. Figures $4 \mathrm{a}$ and $4 \mathrm{~b}$ show the current layout and proposed revised layout of one laboratory in the research object in which student desks can be introduced by using the free space. The revised layout does not disturb laboratory sessions conducted in the laboratory, because the data collected shows that the laboratory is used for laboratory sessions during only one semester and for only one day per week.

The revised layout can accommodate at least fifteen desks for students working on their final project in one laboratory, as shown in Figure 5. This figure shows a close-up view of the student desks illustrated in Figure 4b. According to data provided by one department at the research object, approximately forty-five students on average enroll in the program every year. By utilising three laboratories, all the final year students from one department of the research object can be accommodated to work on their final project.

In Japanese universities, final year students who join particular laboratories normally do so at the beginning of their fourth year. In Indonesia, particularly in the research object, it is possible for students to start working on their project in the laboratory in semester eight or during the last six months of their final project. This is because in Indonesia, particularly for science and engineering programs, students have to complete seven semesters of theory and have only one semester for their final project.

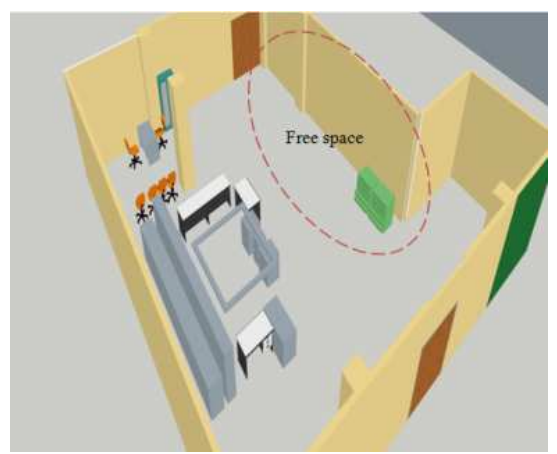

Figure 4a. Current layout laboratory.

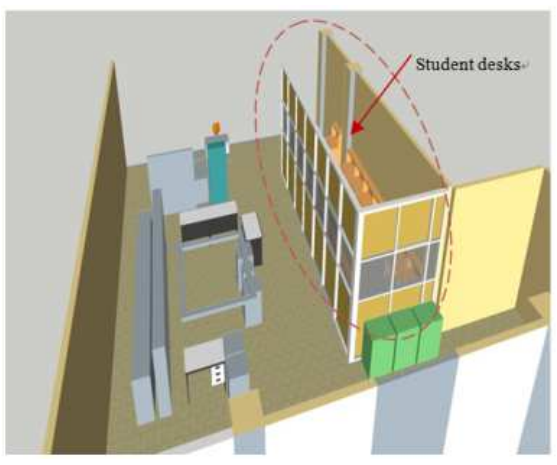

Figure 4b. Revised laboratory layout.

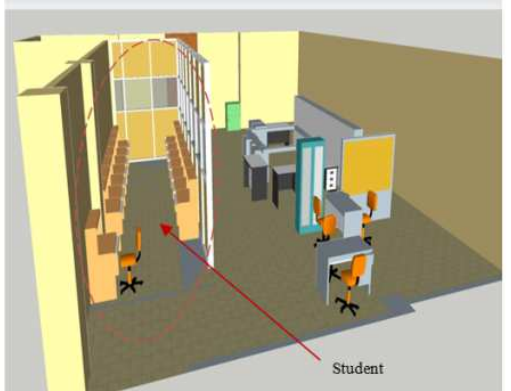

Figure 5. Proposed research desks for students in one research object Laboratory.

\section{Concluding Remarks}

With the current fierce competition in the education sector, higher institutions under MORA, particularly those that offer study in science and technology fields, must improve their academic performance by increasing the number of publications based on research, and the number of patents. We believe that Laboratory-Based Education (LBE), as implemented by most Japanese universities, can be also implemented in MORA universities to improve performance. However, to support LBE implementation, the environment must be adapted to accommodate, for example, a closer relationship between the students and their supervisor, including closer proximity to the supervisor's office, and the provision of student research desks in the laboratory, among other things.

Based on an analysis of the data collected and the observations made in the research object, there are several things that could be improved, such as the utilisation of free space in laboratories to accommodate final year students. Further, the laboratory structure in the research object could be made leaner and the independence of each laboratory enabled, as practised in Japanese universities. By implementing an independent structure, laboratories can strengthen themselves through continuous research and can publish their research findings in high impact journals.

The ideal layout and proposed laboratory structure are only a few important aspects in the implementation of LBE. Another important factor in addition to the layout and structure of the laboratory is the support of the university's top management. Without this support, LBE cannot be implemented successfully.

\section{Acknowledgements}

This work was supported by The Indonesian Ministry of Religious Affairs (DIPA Grant 0084/025-04.1.01/00/2012).

\section{References}

[1] Harijono, T., Mahasiswa di Indonesia Cuma 4,8 Juta, viewed 1 October 2012,

$<$ http://edukasi.kompas.com/read/2011/03/26/13202052/Ma hasiswa.di.Indonesia.Cuma.4.8.Juta>, 2011. 
[2] Ministry of Religious Affairs., Sejarah Pendidikan Islam dan Organisasi Ditjen Pendidikan Islam, viewed 30 September 2012,

$<\mathrm{http}: / /$ pendis.kemenag.go.id/index.php?a=artikel\&id2=seja rahpendis>, 2012.

[3] Wang, Q., Cheng, Y., Liu, N.C. Building World-Class Universities: Different Approaches to a Shared Goal. Rotterdam: Sense Publishers, 2012

[4] World Intellectual Property Organization., Intellectua Property Statistics, viewed 17 October 2012 $<$ http://www.wipo.int/ipstats/en/>, 2012.

[5] Soemantri, S., Labo-based education: its concept and target (goal), PowerPoint slides, Enhance-Unhas Fellowship Seminar, Tokyo, 2011.

[6] Ragunath, M., Lab-Based Research is the Best Education, viewed 15 February 2012

$<$ http://www.nus.edu.sg/ngs/Ragunath_on_Education.pdf $>$, 2007.
[7] Davies, C., Learning and Teaching in Laboratories: An Engineering Subject Centre Guide, The Higher Education Academy Engineering Subject Centre of Loughborough University, Leicestershire, 2008.

[8] Hane, G.., Comparing University-Industry Linkages in the United States and Japan. In Branscomb, L.M., Kodama, F., Florida, R. (Eds.), Industrializing Knowledge. Massachussets: The MIT Press, 1999.

[9] Amar, K. and Ishiharada, S., "Measuring the readiness to adopt a Japanese Laboratory-Based Education model: The Case of Indonesia", Proceedings of the 4th Asian Education Conference, Osaka, 24-28 October 2012.

[10] Ministry of Religious Affairs., Rangking PTAIN Menurut Webometrics, viewed 30 September 2012, $<$ http://www.ranking-ptai.info/>, 2012.

[11] Mintrom, M., "Managing the research function of the university: Pressures and dilemmas", Journal of Higher Education Policy and Management, Vol. 30, No. 3, pp. 231-244, 2008 